\title{
PATENTS IN THE PRODUCTION PROCESS THAT ARE LAYING ON INVENTOR
}

\author{
Putri Indah Sari \\ 155100093 \\ Fakultas Komputer, 448757173 \\ Putriindahsari.Student@Umitra.Ac.Id
}

\begin{abstract}
The problems in this research are: (1) Is the patent in production can be provided to the workers / employees as a inventor? (2) How will the moral rights attached to the inventor to patent the intellectual work produced during the production process? This research uses normative juridical approach. Source of data derived from secondary data that primary legal materials, secondary, and tertiary. The results showed that patents in the production process is not given to the discoverer of workers / employees. The government needs to dissemination of the patents and other intellectual property rights so that a producer of intellectual work so that they know that the law protects what they produce. Governments also need to revise the provisions of Article 12 paragraph (1) Patent Law, where the rights of patent holders fixed on the inventor.
\end{abstract}

Kata Kunci : Patent In The Production Process

\section{A. INTRODUCTION}

A company in carrying out its

business, both from the

beginning or for a long time

owning and acquiring valuable

assets both materially and

immaterial.
1. What is meant by company property is anything that can be made rights to have in the company or something that is very valuable to the company and can bought and sold. The company's assets can be 
tangible or intangible. tangible

usually like everything in the

form of goods both movable

and immovable and the

intangible is usually called

intellectual property rights.

2. From the definition of the company according to Basu Swasta and Ibu Sukotjo there are five important elements, namely organization, production, economic resources, needs and ways that are profitable.

3. Production which is one of the elements of the company, namely all efforts aimed at creating or increasing utility.

4. Intellectual property rights born in the production process in a company are usually in the form of Patent. Because a lot of thought and energy has been implanted in concepts and activities to make products that contribute to cultural development or civilization and legal rights that protect the mind.

5. The patent rights protect the inventor's rights in the field of technology or machinery.
6. According to the World Intellectual Property Organization (WIPO), intellectual property rights are divided into two parts, namely Copyright and Industrial Property Rights. 7. Based on Article 1 of the Paris Convention concerning the protection of industrial property rights in 1883, Patents are included in protection industrial wealth law. In the secondary production process, that is, all businesses that use materials or materials to increase their benefits or processing into other goods.

8. usually a lot produce new discoveries that have never before existed. Patents can be given to new inventions in the form of products, processes, refinement and development of existing products and improvement and development of existing processes. Patents are given by the state to inventors for their inventions in the field of technology and provide exclusive rights to their inventors. Provision of rights by the state is one form of 
legal protection given to inventor.

This is in line with the theory of intellectual property that was proposed by Jhon Locke, who said that the property rights possessed by humans have existed since humans were born. Objects in this case are tangible and intangible objects called intellectual property. On the basis of this theory, legal protection of intellectual property rights is based on two very strong reasons, namely moral rights and commercial matters.

\section{Definition of Intellectual}

\section{Property Rights}

The World Intellectual Property

Right (WIPO) formulates intellectual property as a result good human works created by activities in science, industry, literature and art. The scope of intellectual property rights as formulated by WIPO has broad understanding. It should be emphasized that protected intellectual property rights are not ideas

or ideas, but creations that result from these ideas or ideas.
Therefore Intellectual Property Right (IPR) is a protection against good human work the work in the form of activities in science, industry, literature and art.

\section{Definition of Patents}

According to WIPO, intellectual property rights are usually divided into two parts, namely Copyright (Copy Right) and Industrial Property Right. Specifically concerning rights industrial wealth according to Article 1 of the Paris Convention concerning the Protection of the Right to Wealth Industrial in 1883 which was revised and administered on October 2, 1979 the usual called the Paris Convention, the protection of industrial property law includes: 20

1) Patent

2) Brands

3) Industrial Design Rights

4) Company Name

5) Geographical Indications and Origin Indications. In this study, which will be presented is about the property rights of the Patent 
industry. Said Patents can be used in two senses, first a patent means documents issued by government based on requests stating about an invention and who the inventor is as the owner of the patent or invention concerned. Both patents mean exclusive rights given by the state to the inventor for the results of his invention, for a certain time in carry out the invasion itself and other people are prohibited from carrying out without the permission of their investment.

\section{Patents in the Production}

Process As a condition that an invention can be patented, an invoice must be able to applied in industry, because an invention does not merely contain theoretical values, but must also have practical value. This also means that patents are produced in the production process must have practical value. For example, inventions in the form of products, then the product must be able to produced further, or if the invention is a process then the process must be able to implemented to produce products. In the process of producing nonfood consumption products, for example, production equipment is used in the form of a product maker that can convert materials from various sources into results desired by consumers. In the early stages of the product production process, it must first created a production machine. Thus the existence of the production machine is a intellectual work, which has produced an invention that can be patented so that giving birth to rights to the inventor.

\section{B. CONCLUSION}

Patents produced in the production process, inherent rights to workers or employees that produce such intellectual work. But in Article 12 paragraph (1) the Patent Law says that during the working relationship the patent holder is the one who gives the job, except promised another. Patents are part of Intellectual Property Rights in the field of industrial wealth by 
hence based on the theory of

intellectual property inherent moral

rights and economic rights to

people or anyone who has

produced an invention or invention

provided that the invention

it must have an element of novelty,

have inventive steps and can be

applied in the field

industry. It is hoped that

dissemination regarding Patents

and other intellectual property

rights will be intensified by both

the government and the private

sector, so that producers of

intellectual work can know that the

law protects what they have

produced. The government is also

expected to revise Article 12

paragraph (1) of the Patent Law,

where the patent holder's rights

remain with the inventor.

\section{ACKNOWLEDGEMENT}

University Of Indonesia

University Of Mitra Indonesia

Telkom University

University Of Mellbourne

Saitama University

\section{REFERENCE(Based ISO 690 )}

[1]

A. S. Putra And O. M. Febriani, "Knowledge Management Online Application In Pdam Lampung Province," In Prosiding International Conference On Information Technology And Business (Icitb), 2018, Pp. 181-187.

[2] A. S. Putra, O. M. Febriani, And B. Bachry, "Implementasi Genetic Fuzzy System Untuk Mengidentifikasi Hasil Curian Kendaraan Bermotor Di Polda Lampung," J. Sist. Inf. Dan Manaj. Basis Data, Vol. 1, No. 1, Pp. 21-30, 2018.

[3] O. M. Febriani And A. S. Putra, "Sistem Informasi Monitoring Inventori Barang Pada Balai Riset Standardisasi Industri Bandar Lampung," J. Inform., Vol. 13, No. 1, Pp. 90-98, 2014.

[4] Putra, Arie Setya. "2018 Artikel Struktur Data, Audit Dan Jaringan Komputer." (2018).

[5] Putra, A. S. (2018, July 17). Paperplain Fundamental Create Application With Borland Delphi 7.0 University Of Mitra Indonesia. Retrieved From Osf.Io/Pbrn9.

\section{E. REFERENCE (Based APA)}

Putra, A. S., Aryanti, D. R., \& Hartati, I. (2018, November). Metode SAW (Simple Additive Weighting) sebagai Sistem Pendukung Keputusan Guru Berprestasi (Studi Kasus: SMK Global 


\section{QUIZ Selected Section Class}

Surya). In Prosiding Seminar Nasional Darmajaya (Vol. 1, No. 1, pp. 85-97).

Sari, D. P., Febriani, O. M., \& Putra, A. S. (2018, November). Perancangan Sistem Informasi SDM Berprestasi pada SD Global Surya. In Prosiding Seminar Nasional Darmajaya (Vol. 1, No. 1, pp. 289-294).

Putra, A. S. (2018). Paperplain: Execution Fundamental Create Application With Borland Delphi 7.0 University Of Mitra Indonesia.

Putra, A. S., Sukri, H., \& Zuhri, K. Sistem Monitoring Realtime Jaringan Irigasi Desa (JIDES) Dengan Konsep Jaringan Sensor Nirkabel. IJEIS (Indonesian Journal of Electronics and Instrumentation Systems), 8(2), 221232.

Darmawan, A., Yuliawati, D., Marcella, O., \& Firmandala, R. (2016). Sistem Absensi dan Pelaporan Berbasis Fingerprint dan SMS Gateway. EXPLORE, 7(1).

Febriani, O. M., Wahyuni, T., \& Yusuf, S. (2017). DESIGN OF WEBSITE-BASED INFORMATION SYSTEM FOR EDOCUMENT ADMINISTRASI IN THE COMMUNITY SERVICE UNIT (A Case Study at Rajabasa District). INTERNATIONAL JOURNAL OF COMPUTERS \& TECHNOLOGY, 16(7), 7010-7020.

Febriani, O. M., \& Wahyuni, T. (2017, October). PERANCANGAN SISTEM E-DOCUMENT ADMINISTRASI LOGBOOK PENELITIAN PADA
UNIT LAYANAN DI BANDAR LAMPUNG. In Prosiding Seminar Nasional Darmajaya (Vol. 1, No. 1, pp. 187-194).

Febriani, O. M., \& Permadi, A. B. (2017). Implementasi Sistem Aplikasi Data Bimbingan dan Pelanggaran Siswa pada Sekolah Menengah Atas di Lampung Tengah dengan Metode Analisis dan Desain Sistem Terdistribusi (SSAD). EXPERT, 7(1).

Febriani, O. M., \& Ambarwati, L. (2015). PERANCANGAN APLIKASI PENGOLAHAN DATA PENJUALAN UKM KELANTING KHAS TELO DESA SIDOHARJO KECAMATAN JATI AGUNG KABUPATEN LAMPUNG SELATAN. Jurnal Teknologi Informasi dan Bisnis Pengabdian Masyarakat Darmajaya, 1(1), 77-95.

Febriani, O. M. (2015). Rancang Bangun Aplikasi Ecommercemenggunakan Freewebstore pada UKM Kelanting di Desa Sidoharjo Lampung Selatan. Prosiding Sembistek 2014, 1(02), 446-458. 